\title{
G-Protein Coupled Receptor 182
}

National Cancer Institute

\section{Source}

National Cancer Institute. G-Protein Coupled Receptor 182. NCI Thesaurus. Code C132188.

G-protein coupled receptor 182 (404 aa, $\sim 45 \mathrm{kDa}$ ) is encoded by the human GPR182 gene. This protein plays a role in G protein-coupled receptor signaling. 